\title{
PMS2 Gene Mutation
}

National Cancer Institute

\section{Source}

National Cancer Institute. PMS2 Gene Mutation. NCI Thesaurus. Code C118397.

A change in the nucleotide sequence of the PMS2 gene. 